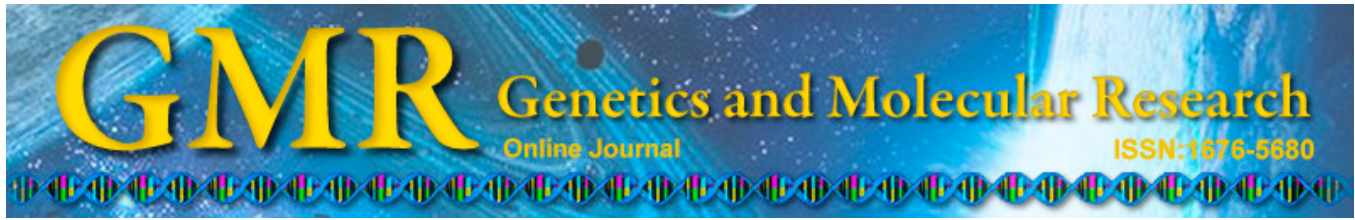

\title{
Fengshui forests conserve genetic diversity: a case study of Phoebe bournei (Hemsl.) Yang in southern China
}

\author{
Y.J. Ge', ${ }^{1,2}$ Y.J. Liu' ${ }^{2}$ A.H. Shen ${ }^{3}$ and X.C. Lin $^{4}$ \\ ${ }^{1}$ School of Forestry, Beijing Forestry University, Beijing, China \\ ${ }^{2}$ Lishui Academy of Forestry Sciences, Lishui, Zhejiang, China \\ ${ }^{3}$ Zhejiang Academy of Forestry Sciences, Hangzhou, Zhejiang, China \\ ${ }^{4}$ The Nurturing Station for the State Key Laboratory of Subtropical Silviculture, \\ Zhejiang Agriculture and Forestry University, Hangzhou, Zhejiang, China \\ Corresponding author: X.C. Lin \\ E-mail: linxcx@163.com
}

Genet. Mol. Res. 14 (1): 1986-1993 (2015)

Received January 15, 2014

Accepted March 26, 2014

Published March 20, 2015

DOI http://dx.doi.org/10.4238/2015.March.20.8

\begin{abstract}
Fengshui forests (sacred groves) are important in traditional Chinese culture and home to many endangered species. These forests may provide protection for some endangered plant species outside the nature reserves, but little is known about their role in genetic conservation. Using inter-simple sequence repeat (ISSR) markers, we compared the genetic diversity of 6 populations of Phoebe bournei (Hemsl.) Yang, a commercially important woody species, which is under second-class national protection and endemic to China. Samples were collected from the nature reserves and Fengshui forests in southern China. Herein, we show that Fengshui forest populations are capable of maintaining some level of genetic diversity. For nature reserve populations, the average $N_{\mathrm{A}}$ and $N_{\mathrm{E}}$ were 1.58 and 1.39 , respectively; and for Fengshui forests, they were 1.39 and 1.12, respectively. For nature reserve populations, Nei's gene diversity $(H)$ and Shannon's index $(I)$ were
\end{abstract}


0.32 and 0.11 , respectively; and for Fengshui forests, they were 0.22 and 0.07 , respectively. We discuss the reasons for the genetic differences between populations of the Fengshui forests and nature reserves and propose conservation strategies for the Fengshui forest.

Key words: Fengshui forest; Phoebe bournei (Hemsl.) Yang; Nanmu; Genetic diversity; Nature reserves

\section{INTRODUCTION}

The negative impacts of forest degradation and industrialization are complex and broad, including species extinctions and the loss of genetic diversity (Chapin et al., 2000; Feyissa et al., 2007). Increasing numbers of species are becoming endangered, with some populations restricted to nature reserves. Therefore, nature reserves play an important role in the conservation of the genetic diversity for such species (Sanderson et al., 2002; Chen et al., 2009).

In China, the Fengshui forests (sacred groves) are home to many endangered species and, alongside nature reserves, are important for the protection of endangered species (Jan et al., 2007). Fengshui forests are man-made forests, usually located near a village, backyard, or temple, that have been sown from seeds or are an extension of a natural forest. They are important in traditional Chinese culture and are strictly managed (e.g., the felling of large trees is forbidden) (Yuan and Liu, 2009). Fengshui forests have spiritual symbolic meanings and can be traced back to the Shang (1700-1100 BC) and Zhou (1066-256 BC) Dynasties; they are very popular in China and other East Asian countries that were historically influenced by the Chinese culture (Kim, 2005).

Many studies have shown that the Fengshui forests have great value to ecology, biodiversity, and human livelihood on a daily basis (Zhong and Boris, 2007). However, there are few reports on the role of Fengshui forests in conserving genetic diversity and comparisons of genetic diversity between nature reserves and Fengshui forests.

To understand the potential of Fengshui forests for genetic conservation, we chose an endemic Chinese plant, Phoebe bournei (Hemsl.) Yang. Also known as Nanmu, it is a commercially important woody species and considered an excellent material by Chinese ancient civilizations because of its brilliant color and remarkable durability. Nanmu has been used intensively over the centuries, especially during the Ming and Qing Dynasties, for high-grade furniture manufacturing, shipbuilding, temple decoration, and Palaces such as the Forbidden City. P. bournei is under second-class national protection in China (IUCN, 2012). Currently, populations can be found only in several nature reserves and Fengshui forests.

We sequenced inter-simple sequence repeats (ISSRs) to compare the genetic diversity of P. bournei populations in Fengshui forests and nature reserves (Aga et al., 2005). We addressed the following: 1) whether Fengshui forests can somehow conserve genetic diversity; 2) comparisons of the genetic diversity of $P$. bournei populations located in the nature reserves and Fengshui forests; and 3) protection of populations in the Fengshui forests. 


\section{MATERIAL AND METHODS}

\section{Plant material and DNA isolation}

P. bournei was once abundant in southern China, but many populations have been reduced to isolated stands containing very few individuals, and relatively large populations are only found in Zhejiang, Fujian, Guangdong, Hunan, and Jiangxi Provinces (Ge et al., 2012; Zhang et al., 2012). Based on this distribution, we chose 6 populations ( 3 from the Fengshui forests and 3 from the nature reserves) throughout these 5 provinces (Figure 1; Table 1). We made sure that the leaf sample sizes from each population were similar in order to avoid effects of population size on genetic diversity. Total genomic DNA was extracted from each sample using a modified ammonium bromide (CTAB) method (Doyle and Doyle, 1987). The DNA was diluted to a working concentration of $20 \mathrm{ng} / \mu \mathrm{L}$.

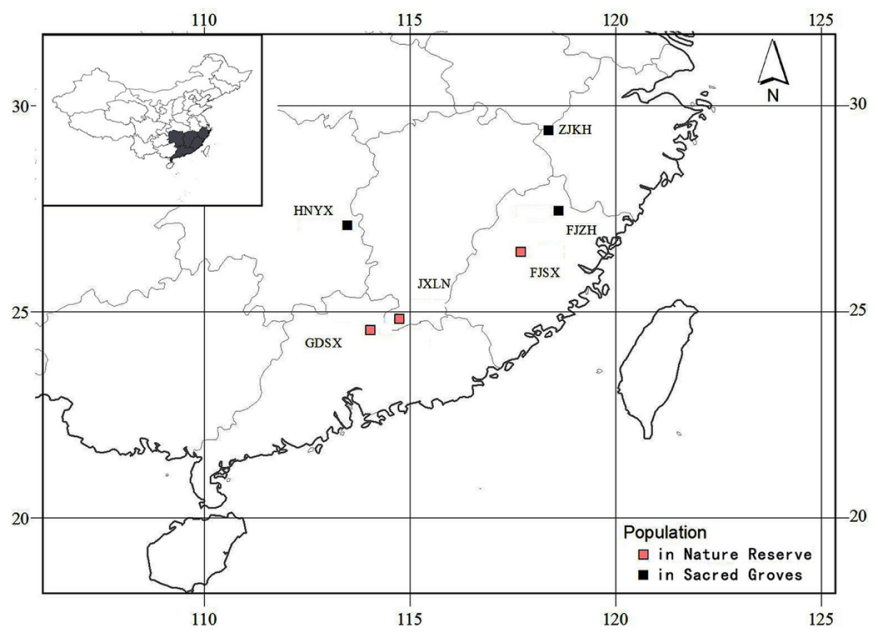

Figure 1. Geographical distribution of the sample populations used in the present study.

Table 1. Ecological and geographical parameters of the 6 populations sampled.

\begin{tabular}{|c|c|c|c|c|c|c|}
\hline $\begin{array}{l}\text { Population } \\
\text { code }\end{array}$ & Zone/Province & $\begin{array}{l}\text { Latitude }(\mathrm{N}) / \\
\text { longitude(E) }\end{array}$ & Elevation (m) & $\begin{array}{c}\text { Annual } \\
\text { rainfall }(\mathrm{mm})\end{array}$ & $\begin{array}{c}\text { Annual mean } \\
\text { temperature }\left({ }^{\circ} \mathrm{C}\right)\end{array}$ & $\begin{array}{l}\text { Population } \\
\text { area/ha }\end{array}$ \\
\hline FJSX & Shaxian/Fujian & $26^{\circ} 444 / 117^{\circ} 705$ & 540 & 1662 & 19.2 & 17.35 \\
\hline FJZH & Zhenghe/Fujian & $27^{\circ} 443 / 118^{\circ} 616$ & 520 & 1636 & 18.5 & 4.13 \\
\hline GDSX & Shixing/Guangdong & $24^{\circ} 723 / 114^{\circ} 256$ & 580 & 1468 & 19.6 & 5.33 \\
\hline HNYX & Youxian/Hunan & $27^{\circ} 098 / 113^{\circ} 492$ & 100 & 1410 & 17.8 & 1.05 \\
\hline JXLN & Longnan/Jiangxi & $24^{\circ} 582 / 114^{\circ} 44$ & 280 & 1981 & 17.4 & 13.33 \\
\hline ZJKH & Kaihua/Zhejiang & $29^{\circ} 396 / 118^{\circ} 379$ & 440 & 1901 & 16.0 & 0.78 \\
\hline
\end{tabular}

\section{ISSR analysis}

ISSR primers (Table 2) were synthesized by the Shanghai Sangon Biological Engineering Technology \& Services Co., Ltd. based on the sequences from the Biotechnology Laboratory, University of British Columbia, Canada (UBC Primers). The polymerase chain 
reaction (PCR) amplification was conducted in a total volume of $20 \mu \mathrm{L}$; the reaction mixture contained $60 \mathrm{ng}$ genomic DNA, $500 \mathrm{nM}$ primers, $0.2 \mathrm{mM}$ dNTPs, 1.0 unit Taq polymerase, 1.8 $\mathrm{mM} \mathrm{MgCl}_{2}, 10 \mathrm{mM}$ Tris-HCl, $\mathrm{pH} 9.0,50 \mathrm{mM} \mathrm{KCl}$, and 2\% formamide (deionized). The amplification was performed on the thermocycler PCR 9700 (Applied Biosystems, Foster City, CA, USA) by initial denaturing at $94^{\circ} \mathrm{C}$ for $3 \mathrm{~min}$; followed by 35 cycles each of $94^{\circ} \mathrm{C}$ for $30 \mathrm{~s}$, $53^{\circ} \mathrm{C}$ for $45 \mathrm{~s}$, and $72^{\circ} \mathrm{C}$ for $90 \mathrm{~s}$; and a final elongation at $72^{\circ} \mathrm{C}$ for $7 \mathrm{~min}$. PCR products were separated by electrophoresis on a $1.8 \%$ agarose gel in $1 \mathrm{X}$ TAE buffer, stained with ethidium bromide for visualization, and later photographed under UV light (Lin et al., 2009).

\begin{tabular}{|c|c|c|c|c|}
\hline \multirow[t]{2}{*}{ Primer code } & \multirow[t]{2}{*}{ Sequences from the 5 ' to 3 ' ends } & \multirow[t]{2}{*}{ Reproducible bands } & \multicolumn{2}{|c|}{ Polymorphic bands } \\
\hline & & & No. & Percent (\%) \\
\hline 1 & ACACACACACACACACT & 7 & 4 & 57 \\
\hline 4 & ACACACACACACACACAG & 5 & 3 & 60 \\
\hline 17 & GACAGACAGACAGACA & 6 & 4 & 67 \\
\hline 23 & ACACACACACACACACTA & 6 & 6 & 100 \\
\hline 25 & ACACACACACACACACCA & 5 & 3 & 60 \\
\hline 32 & AGAGAGAGAGAGAGAGAC & 7 & 7 & 100 \\
\hline 33 & AGAGAGAGAGAGAGAGAT & 5 & 5 & 100 \\
\hline 35 & AGAGAGAGAGAGAGAGTA & 6 & 6 & 100 \\
\hline 36 & AGAGAGAGAGAGAGAGTC & 5 & 4 & 80 \\
\hline 42 & ACACACACACACACACCG & 6 & 5 & 83 \\
\hline 44 & ACACACACACACACACGA & 6 & 6 & 100 \\
\hline 46 & ACACACACACACACACGG & 6 & 5 & 83 \\
\hline 47 & ACACACACACACACACGT & 6 & 5 & 83 \\
\hline 56 & AGAGAGAGAGAGAGAGTT & 6 & 6 & 100 \\
\hline 74 & ACTGACTGACTGACTG & 6 & 6 & 100 \\
\hline 818 & CACACACACACACACAG & 4 & 4 & 100 \\
\hline 835 & AGAGAGAGAGAGAGAGYC & 5 & 3 & 60 \\
\hline 846 & CACACACACACACACART & 7 & 6 & 86 \\
\hline Mean & & 5.7 & 4.8 & 84 \\
\hline Total & & 104 & 88 & 85 \\
\hline
\end{tabular}

\section{Data scoring and analysis}

For each type of marker, only clear and intense bands in the gel were scored as present (1); all others were scored as absent (0). Genetic similarity was analyzed using the software package NTSYS-PC Version 2.10.E (Rohlf, 2000) based on Dice's coefficient (Dice, 1945) with the ISSR data. We used the POPGENE software v3.2 (Yeh et al., 1999) to compute gene diversity and measures of population differentiation. The total genetic diversity $\left(H_{\mathrm{T}}\right)$, within population genetic diversity $\left(H_{\mathrm{S}}\right)$, among population genetic diversity $\left(D_{\mathrm{ST}}\right)$, and coefficient of genetic differentiation $\left(G_{\mathrm{ST}}\right)$ were related by the following expression according to Nei (1977):

$$
H_{\mathrm{T}}=H_{\mathrm{S}}+D_{\mathrm{ST}} \text {, and } G_{\mathrm{ST}}=D_{\mathrm{ST}} / H_{\mathrm{T}}
$$

(Equation 1)

Analysis of molecular variance (AMOVA) was performed using GenALEx6 to describe genetic structure and variability within and between populations (Peakall and Smouse, 2006).

\section{RESULTS}

The 18 ISSR primers produced a total of 104 scorable bands; 88 bands ( $84.61 \%)$ were 
polymorphic across 60 P. bournei leaf samples collected from 6 populations. Approximately 3-7 bands were obtained from each primer, with an average of 4.8 per primer (Table 2).

The $H_{\mathrm{T}}, H_{\mathrm{S}}, D_{\mathrm{ST}}$, and $G_{\mathrm{ST}}$ of all 6 populations were $0.33,0.13,0.20$, and 0.39 , respectively. The results of the AMOVA (Table 3) also showed significant genetic differences $(\mathrm{P}<$ 0.001 ) among the populations (57.21\%).

The proportion of polymorphic bands within populations varied from 16.35 to $61.54 \%$ for the HNYX and FJSX populations, respectively, with a mean of $36.86 \%$ (Table 4). $H$ and Shannon's index $(I)$ estimates are given in Table 4 . The HNYX population exhibited the lowest genetic diversity in accordance with the polymorphic fragment percentage. The $N_{\mathrm{A}}$ of populations located in the nature reserves ranged from 1.54 to 1.62 , and varied from 1.06 to 1.12 for populations located in the Fengshui forests. The effective number of alleles $\left(N_{\mathrm{E}}\right)$ varied from 1.38 to 1.40 in populations located in the nature reserves and ranged from 1.11 to 1.14 for populations located in the Fengshui forests. The $H$ value of all 6 populations varied from 0.06 to 0.24 , with an average of 0.15 . The $I$ value ranged from 0.09 to 0.35 , with an average of 0.22 . $H$ and $I$ inferred a very significant difference between populations in the Fengshui forests and those in the nature reserves but not among the populations of the 3 Fengshui forests or the 3 nature reserves.

Populations in the nature reserves had higher genetic diversity than those in the Fengshui forests (Table 4). Within-population genetic diversity was the lowest in the 3 Fengshui forest populations (i.e., HNYX followed by ZJKH and FJZH). Table 5 shows Nei's (1978) unbiased genetic distances between these populations. The largest genetic distance (0.37) was found between the ZJKH and JXLN populations, and the smallest genetic distance (0.18) was observed between the JXNL and GDSX populations.

Table 3. Summary of the analysis of molecular variance (AMOVA).

\begin{tabular}{|c|c|c|c|c|c|c|c|}
\hline & Source of variation & df & SSD & MSD & Var. & Total (\%) & $\mathrm{P}$ \\
\hline \multirow{2}{*}{$\begin{array}{l}\text { Populations } \\
\text { in nature reserve }\end{array}$} & Among populations & 2 & 195.48 & 97.74 & 7.55 & 43.84 & $<0.001$ \\
\hline & Within populations & 33 & 319.10 & 9.67 & 9.67 & 56.16 & $<0.001$ \\
\hline \multirow{2}{*}{$\begin{array}{l}\text { Populations } \\
\text { in Fengshui forest }\end{array}$} & Among populations & 2 & 218.56 & 109.28 & 11.91 & 78.28 & $<0.001$ \\
\hline & Within populations & 26 & 85.93 & 3.31 & 3.31 & 21.72 & $<0.001$ \\
\hline \multirow[t]{2}{*}{ Total populations } & Among populations & 5 & 540.01 & 108.00 & 9.38 & 57.21 & $<0.001$ \\
\hline & Within populations & 60 & 420.80 & 7.01 & 7.01 & 42.79 & $<0.001$ \\
\hline
\end{tabular}

SSD, sum of squared deviation; MSD, mean squared deviation; $\mathrm{P}$, significance of the variance components after 999 random permutations. Both "among population" and "within population" values are considered to be highly significant at $\mathrm{P}<0.001$

Table 4. The genetic diversity of the different provenances of Phoebe bournei.

\begin{tabular}{llcccccc}
\hline & Population & $\begin{array}{c}\text { Polymorphic } \\
\text { loci number }\end{array}$ & $\begin{array}{c}\text { Polymorphic } \\
\text { loci percent }\end{array}$ & $N_{\mathrm{A}}$ & $N_{\mathrm{E}}$ & Nei's $H$ & Shannon's $I$ \\
\hline Populations in & FJSX & 64 & 61.54 & $1.62 \pm 0.15^{\mathrm{aA}}$ & $1.40 \pm 0.14^{\mathrm{aA}}$ & $0.24 \pm 0.02^{\mathrm{aA}}$ & $0.35 \pm 0.03^{\mathrm{aA}}$ \\
nature reserve & GDSX & 62 & 59.61 & $1.54 \pm 0.15^{\mathrm{aA}}$ & $1.39 \pm 0.14^{\mathrm{aA}}$ & $0.21 \pm 0.02^{\mathrm{aA}}$ & $0.29 \pm 0.03^{\mathrm{aA}}$ \\
& JXLN & 60 & 57.69 & $1.58 \pm 0.15^{\mathrm{aA}}$ & $1.38 \pm 0.14^{\mathrm{aA}}$ & $0.22 \pm 0.02^{\mathrm{aA}}$ & $0.32 \pm 0.03^{\mathrm{aA}}$ \\
& Mean & $62 \pm 2^{\mathrm{aA}}$ & $59.61 \pm 1.93^{\mathrm{aA}}$ & $1.58 \pm 0.14^{\mathrm{aA}}$ & $1.39 \pm 0.11^{\mathrm{aA}}$ & $0.22 \pm 0.02^{\mathrm{aA}}$ & $0.32 \pm 0.03^{\mathrm{aA}}$ \\
Populations in & HNYX & 17 & 16.35 & $1.06 \pm 0.14^{\mathrm{bB}}$ & $1.11 \pm 0.12^{\mathrm{bB}}$ & $0.06 \pm 0.01^{\mathrm{bB}}$ & $0.09 \pm 0.011^{\mathrm{bB}}$ \\
Fengshui forest & ZJKH & 20 & 19.23 & $1.09 \pm 0.14^{\mathrm{bB}}$ & $1.12 \pm 0.13^{\mathrm{bB}}$ & $0.08 \pm 0.01^{\mathrm{bB}}$ & $0.11 \pm 0.02^{\mathrm{bB}}$ \\
& FJZH & 23 & 22.12 & $1.12 \pm 0.15^{\mathrm{bB}}$ & $1.14 \pm 0.12^{\mathrm{bB}}$ & $0.08 \pm 0.01^{\mathrm{bB}}$ & $0.12 \pm 0.02^{\mathrm{bB}}$ \\
& Mean & $20 \pm 3^{\mathrm{bB}}$ & $19.23 \pm 2.89^{\mathrm{bB}}$ & $1.09 \pm 0.13^{\mathrm{bB}}$ & $1.12 \pm 0.12^{\mathrm{bB}}$ & $0.07 \pm 0.01^{\mathrm{bB}}$ & $0.11 \pm 0.02^{\mathrm{bB}}$ \\
\hline
\end{tabular}

Lowercase and capital letters indicate statistically significant differences between populations at $\mathrm{P}<0.05$ and $\mathrm{P}<$ 0.01 , respectively. 
Table 5. Nei's (1978) unbiased genetic distance for 6 Phoebe bournei populations.

\begin{tabular}{lcccccc}
\hline Population & FJSX & FJZH & GDSX & HNYX & JXLN & ZJKH \\
\hline FJSX & - & & & & & \\
FJZH & 0.25 & - & - & & & \\
GDSX & 0.22 & 0.29 & 0.30 & - & - & \\
HNYX & 0.30 & 0.26 & 0.18 & 0.28 & 0.37 & - \\
JXLN & 0.23 & 0.32 & 0.35 & 0.36 & \\
ZJKH & 0.22 & 0.34 & &
\end{tabular}

\section{DISCUSSION}

\section{Fengshui forests can conserve some genetic diversity}

Genetic diversity is essential for effective genetic conservation of species (Millar and Marshall, 1991), and the value of conserving genetic diversity has received significant attention (Joshi et al., 2007; Cao et al., 2009). Fengshui forest population $N_{\mathrm{A}}$ and $N_{\mathrm{E}}$ values reached 1.09 and 1.12, respectively; and those for the nature reserves reached 1.58 and 1.39 , respectively (Table 4). Despite very significant differences between forest and reserve populations, a certain amount of genetic diversity was preserved in the Fengshui forests. Because Fengshui forests have been strictly protected, most $P$. bournei individuals in these populations are very large and hundreds of years old, and they may have maintained many excellent genes adapted to the environment that could be useful for molecular breeding. We found that most $P$. bournei populations were distributed throughout remote areas at the junctions of provinces (Figure 1) where there is little interference from human activities, which is probably one of the reasons that these populations have survived over the years.

\section{Reasons for lower genetic diversity than that of the nature reserves}

There may be a number of reasons why P. bournei genetic diversity was lower in the Fengshui forest populations than those in the nature reserves. First, Fengshui forest populations are smaller, and we expect more genetic diversity in large populations than small populations (Savolainen and Pyhäjärvi, 2007). Second, we know that almost all Fengshui forests are located nearby villages where human interference is greater than that in the nature reserves. Pollination and seed dispersal behaviors will certainly be different when compared to those in the nature reserves, thus affecting the breeding system and leading to a lower level of genetic diversity (Xu et al., 2012).

The most significant reason for the lower genetic diversity in Fengshui forest populations is likely because they did not originate from natural forests but were planted by village founders. Zhuang and Gorlett (1997) also suggest that Fengshui forests in Hong Kong were afforestated. The low genetic diversity of Fengshui forests could be a result of seedling collection from a limited number of parent plants and a combination of selective harvesting for timber, firewood, and other products under village management. Consistent with our results, the difference in genetic diversity between natural populations and planted stands of Inga edulis populations was statistically significant (Hollingsworth et al., 2005). 


\section{Conservation suggestions}

Many Fengshui forests have been established since the settlement of villages, and they are not the same as the home-garden systems, which can be maintained by multiple collections from diverse wild populations over several years (Shrinidhi and Sathish, 2009; Gao et al., 2012). Forest trees in general have long generation times and life spans that can last up to hundreds of years (Savolainen and Pyhäjärvi, 2007); the regrowth of forests has not be an ongoing process, and the reintroduction of material form multiple wild populations may have been difficult because ancient human populations lacked the modern technical advances of seed orchard establishment. The matter of protecting and improving genetic diversity of populations located in the Fengshui forests is an urgent problem.

First of all, Fengshui forests should be protected not only for their genetic diversity but also for their cultural contributions. Thus, an appeal should be proposed to protect these populations in situ. We should seek to control human interference and protect pollination and seed dispersal systems. Seedlings in these populations must be protected and prevented from harvestation for firewood.

Second, low genetic diversity and small communities cause instability in Fengshui forest populations. We can introduce seedlings from other populations that have large genetic distances to increase the number of individuals and genetic diversity in these Fengshui forest populations. We should apply modern seed orchard techniques to reconstruct populations located within the Fengshui forests to promote genetic diversity (Chaisurisri and Kassaby, 1994). We hope our findings are taken into account with regard to the development of conservation management policies for Fengshui forests.

\section{ACKNOWLEDGMENTS}

We thank Dr. Gao Jie in XTBG for kindly providing constructive comments on the manuscript. Research was supported by the Zhejiang Provincial Key Scientific and Technological Innovation Team Funded Projects (\#2011R50027).

\section{REFERENCES}

Aga E, Bekele E and Bryngelsson T (2005). Inter-simple sequence repeat (ISSR) variation in forest coffee trees (Coffea arabica L.) populations from Ethiopia. Genetica 124: 213-221.

Cao CP, Gailing O, Siregar IZ, Siregar UJ, et al. (2009). Genetic variation in nine Shorea species (Dipterocarpaceae) in Indonesia revealed by AFLPs. Tree Genet. Genomes. 5: 407-420.

Chaisurisri K and Kassaby YA (1994). Genetic diversity in a seed production population vs natural populations of Sitka Spruce. Biodivers. Conserv. 3: 512-523.

Chapin FS 3rd, Zavaleta ES, Eviner VT, Naylor RL, et al. (2000). Consequences of changing biodiversity. Nature 405: 234-242.

Chen YH, Tang ZY and Fang JY (2009). Distribution of nature reserves and status of biodiversity protection in China. Biodiver Sci. 17: 664- 674.

Dice LR (1945). Measures of the amount of ecologic association between species. Ecology 26: 297-302.

Doyle JJ and Doyle JL (1987). A rapid DNA isolation procedure for small quantities of fresh leaf tissue. Phytochem. Bull. 19: 11-15.

Feyissa T, Nybom H, Bartish IV and Welander M (2007). Analysis of genetic diversity in the endangered tropical tree species Hagenia abyssinica using ISSR markers. Genet. Resour. Crop Ev. 54: 947-958.

Gao J, He T and Li Q (2012). Traditional home-garden conserving genetic diversity: a case study of Acacia pennata in 
southwest China. Conserv. Genet. 13: 891-898.

Ge YJ, Wang JF, Fang W and Ye RH (2012). Distribution pattern of Phoebe bournei Yang and the characteristics of climate. Acta Agriculturae Universitatis Jiangxiensis 34: 749-753.

Hollingsworth PM, Dawson IK, Goodall-Copestake WP, Richardson JE, et al. (2005). Do farmers reduce genetic diversity when they domesticate tropical trees? A case study from Amazonia. Mol. Ecol. 14: 497-501.

IUCN (2012). IUCN Red List of Threatened Species. The International Union for Conservation of Nature, MA.

Jan S, Anthony A, Danica A, Kurt H, et al. (2007). Tibetan sacred sites conserve old growth trees and cover in the eastern Himalayas. Biodivers. Conserv. 16: 693-706.

Joshi SP, Josh P and Dhawan V (2007). Analysis of genetic diversity among Swertia chirayita genotypes. Biol. Plant. 51: 764-768.

Kim AE (2005). Nonofficial religion in South Korea: prevalence of fortunetelling and other forms of divination. Rev. Relig. Res. 46: 284-302.

Lin XC, Ruan XS, Lou YF, Guo XQ, et al. (2009). Genetic similarity among cultivars of Phyllostachys pubesce. Plant Syst. Evol. 277: 67-73.

Millar CI and Marshall KA (1991). Allozyme variation of Port-Orford-cedar (Chamaceyparis lawsoniana): implications for genetic conservation. For. Sci. 37: 1060-1077.

Nei M (1977). F-statistics and analysis of gene diversity in subdivided populations. Ann. Hum. Genet. 41: 225-233.

Nei M (1978). Estimation of average heterozygosity and genetic distance from a small number of individuals. Genetics 89: 583-590.

Peakall R and Smouse PE (2006). GenALEx 6.5: genetic analysis in Excel. Population genetic software for teaching and research-an update. Bioinformatics 6: 2537-2539.

Rohlf FJ (2000). Ntsys-pc. Numerical taxonomy and multivariate analysis ststem. Version 2.10e. Applied Biostatics, New York.

Sanderson EW, Jaiteh M, Levy MA, Redford KH, et al. (2002). The human footprint and the last of the wild. Biodiver. Sci. 52: 891-904.

Savolainen O and Pyhäjärvi T (2007). Genomic diversity in forest trees. Curr. Opin. Plant Biol. 10: 162-167.

Shrinidhi A and Sathish BN (2009). Comparing tree diversity and composition in coffee farms and sacred forests in the Western Ghats of India. Biodivers. Conserv. 18: 987-1000.

Xu W, Yang Q, Huai H and Liu A (2012). Development of EST-SSR markers and investigation of genetic relatedness in tung tree. Tree Genet. Genomes 8: 933-940.

Yeh FC, Yang RC, Boyle TBJ, Ye ZH, et al. (1999). PopGene Version 3.2: The user-friendly shareware for population genetic analysis. Molecular Biology and Biotechnology Center, University of Alberta, Edmonton.

Yuan JW and Liu JL (2009). Fengshui forest management by the Buyi ethnic minority in China. Forest Ecol. Manag. 257: 2002-2009.

Zhang R, Zhou Z, Jin G, Wang S, et al. (2012). Genetic diversity and differentiation within three species of the family Lauraceae in southeast China. Biochem. Syst. Ecol. 44: 317-324.

Zhong ZQ and Boris DC (2007). Fengshui - a systematic research of vernacular sustainable development in ancient China and its lessons for future. In: 7th UK CARE Annual General Meeting. UK Chinese Association of Resources and Environment, London, 15 September 2007.

Zhuang XY and Gorlett RT (1997). Forest and forest succession in Hong Kong, China. J. Trop. Ecol. 14: 857-866. 